\title{
Domainal fabric development, associated microstructures and $P-T$ records attesting to polymetamorphism in a granulite complex of the Eastern Ghats granulite belt, India
}

\author{
RAJIB KAR \\ Department of Geology, J. K. College, Purulia 723 101, West Bengal, India. \\ e-mail: rajib_kar@hotmail.com
}

\begin{abstract}
The granulite complex around Jenapore, Orissa, Eastern Ghats granulite belt, bears the imprint of two episodes of strong deformation $\left(\mathrm{D}_{1}\right.$ and $\left.\mathrm{D}_{2}\right)$ attended with foliation (fabric) development $\left(\mathrm{S}_{1}\right.$ and $\mathrm{S}_{2}$ ). Two distinct metamorphic events at $P-T$ conditions of $\sim 900^{\circ} \mathrm{C}$ at $\sim 9 \mathrm{kbar}$ and $\sim 600^{\circ} \mathrm{C}$ at $\sim 6$ kbar are correlated with $\mathrm{D}_{1}$ and $\mathrm{D}_{2}$ respectively. The reaction textures in $\mathrm{S}_{1}$-microdomains are interpreted to be the product of near isobaric cooling at $\sim 9 \mathrm{kbar}$ from $950^{\circ} \mathrm{C}$ to $600^{\circ} \mathrm{C}$, whereas those in the $\mathrm{S}_{2}$-microdomains are considered to be the result of an up-pressure trajectory from $\sim 6 \mathrm{kbar}$ at $600^{\circ} \mathrm{C}$. The $\mathrm{D}_{1}-\mathrm{M}_{1}$ high $P-T$ granulite event is interpreted to be Archean in age (ca. $3 \mathrm{Ga}$ ) on the basis of the isotopic data obtained from the charnockite suite of the area. The later relatively low $P-T$ granulite facies event, attendant to $\mathrm{D}_{2}-\mathrm{S}_{2}$ is considered to be related to the Grenvillian orogeny as represented by the dominant isotopic record in the belt.
\end{abstract}

\section{Introduction}

Regional granulite terranes within Precambrian shield areas, with no record of gradual transitions to lower grade zones, are typified by the preservation of relatively uniform granulite assemblages, implying similar physical conditions over very large regions (Harley 1992). Moreover, many of these terranes record high-grade metamorphism and deformational events pre-dating major crustal episodes such as the Grenvillian. The metamorphic evolution of these belts is certainly very important and likely to be complex. The Eastern Ghats granulite belt of India, which records the imprint of both Grenvillian and pre-Grenvillian high-grade metamorphism (Mezger and Cosca 1999; Bhattacharya et al 2001), is one such polymetamorphic granulite belt that is of major importance in reconstructing past continental configuration.

During the last decade investigations in parts of the regional granulite belt of the Eastern Ghats have revealed many complexities. Principal findings are:

(a) the polyphase deformation (Sarkar et al 1981; Halden et al 1982; Bhattachayra et al 1994; Kar 1995; Bhattacharya 1996, 1997; Shaw 1996),

(b) complex and multi-stage history of granulite facies metamorphism (Dasgupta et al 1994, 1995; Sen et al 1995; Shaw and Arima 1996a, 1996b, 1997, 1998; Dasgupta and Sengupta 1998; Rickers et al 1998; Bhattacharya and Kar 2002),

(c) partial melting under granulite facies conditions (Dasgupta et al 1992; Sen and Bhattacharya 1997; Bhattacharya et al 2001; Bhattacharya and Kar 2002), and

(d) diverse styles of melting (Mukhopadhyay and Bhattacharya 1997; Sen and Bhattacharya 1997, 2000). 


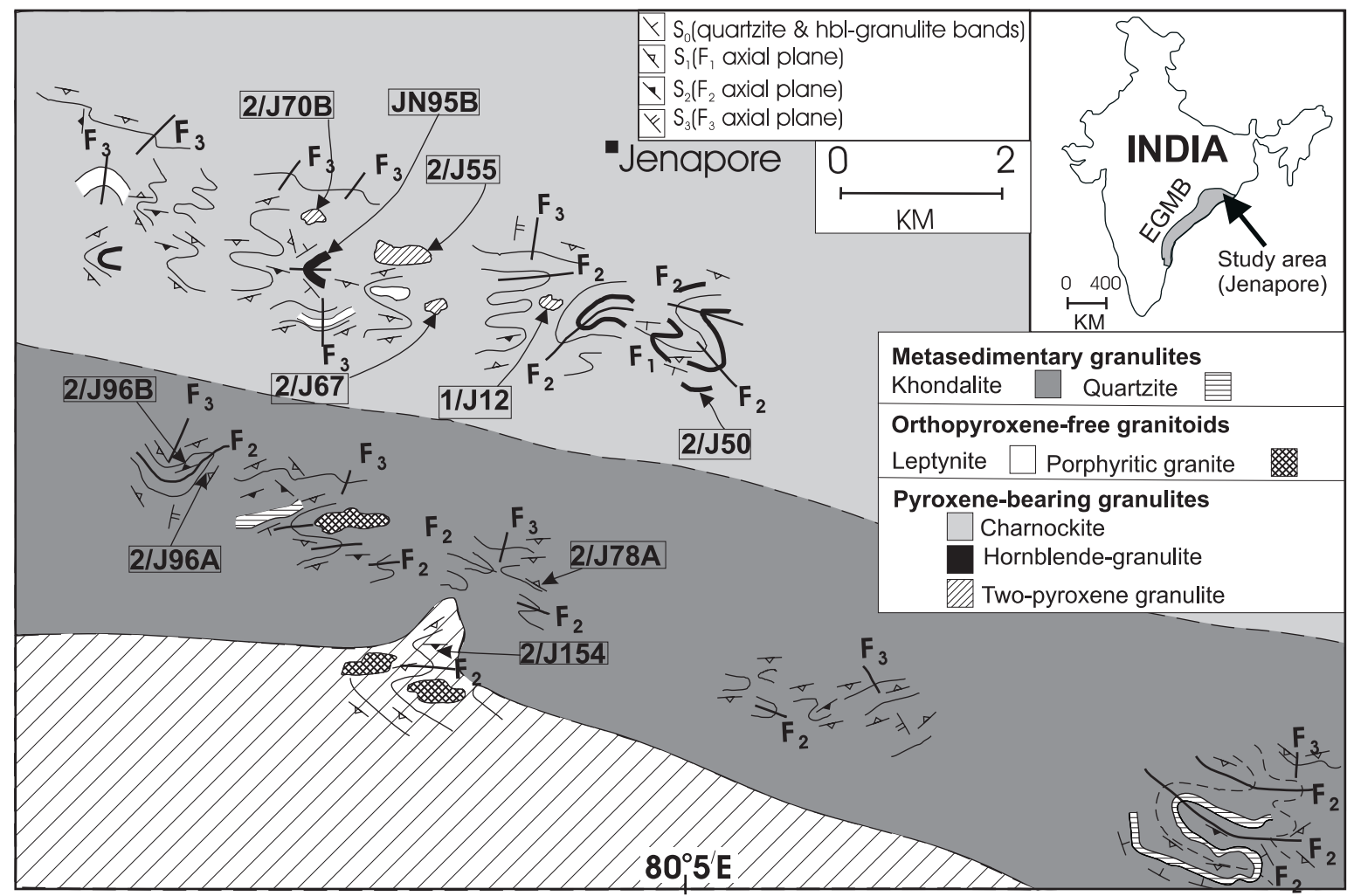

Figure 1. Simplified geological map of the area around Jenapore, Orissa. Inset shows the location map. Locations of the analysed samples are given in rectangular boxes.

From different parts of this large belt, different $P-T$ estimates and $P-T-t$ paths have been reported. Three common $P-T$ clusters or domains can be identified: high $P-T$ conditions of $9.5-$ $10 \mathrm{kbar}$ at $900-1000^{\circ} \mathrm{C}$; intermediate $P-T$ conditions near $700^{\circ} \mathrm{C}$ at $6-8 \mathrm{kbar}$; and lower pressure condition in the range of $4.5-6 \mathrm{kbar}$ at $650-700^{\circ} \mathrm{C}$. These sets of conditions are recorded in different rock samples from many localities (cf. Sen et al 1995 and references therein). Contrasting, post-peak isobaric cooling and isothermal decompression have been recorded from several areas in the Eastern Ghats granulite belt (Lal et al 1987; Sengupta et al 1990; Dasgupta et al 1991, 1993, 1994; Sen et al 1995; Bhattacharya 1996; Shaw and Arima 1996b; Mohan et al 1997). However, barring a few (Bhattacharya and Kar 2002), the prograde $P-T$ trajectory is rarely documented. In addition, the significance of the extreme metamorphism, and the regional context of the post-peak $P-T$ paths, is not clear as the ages of the assemblages is poorly constrained. Moreover, except a few, most of the studies lack integration between deformation history, metamorphic evolution and age data from the assemblages of a locality. Nevertheless, the possibility of polymetamorphism cannot be denied.
Some earlier studies emphasized the repeated metamorphism in the Eastern Ghats granulite belt (Naqvi and Rogers 1987; Halden et al 1982). Especially, Grew and Manton (1986) dated the $1 \mathrm{Ga}$ granulite-facies metamorphism in this belt, but had strongly opined the possibility of Archaean or early Proterozoic high-grade metamorphism. However, recent findings emphasized that Eastern Ghats belt possibly represents a collage of several crustal provinces (Chetty 2001; Rickers et al 2001; Bhattacharya and Kar 2002). Contextually, in his review on the Proterozoic granulite terranes, Harley (1992) also emphasized this possibility and stated that the pre-Grenvillian high-grade terrains not only consist of reworked older crustal material, but may also contain newly accreted materials. Moreover, Barton et al (1994) noted that in complex terrain the $P-T$ loops might be apparent which may actually link $P-T$ vectors of isotopically distinct metamorphic cycle. Hence, in complex terrain like Eastern Ghats belt, to interpret the retrieved $P-T$ data one has to be very cautious. A more comprehensive approach, considering the all-round information from the local assemblages, is required and this is the major focus of the present communication. 


\section{Geological setting}

\subsection{Lithologic types and field relations}

The granulite complex in and around Jenapore, Orissa is primarily composed of suites of metasedimentary granulites and pyroxenebearing granulites (figure 1). Different varieties of orthopyroxene-free granitoids namely, leptynite and prophyritic granite are also exposed. The metasedimentary granulites are of two types, namely, khondalite and quartzite, of which khondalite is the mappable unit. Pyroxene-bearing granulites are mainly charnockites, while enderbite, two-pyroxene granulite and hornblende granulite are minor but significant members.

Khondalite generally preserves the pervasive gneissosity defined by the alternate quartz-rich and ferromagnesian mineral rich layers. Quartzite mostly occurs as minor bands within the khondalite, concordant to the pervasive gneissosity. Locally, the quartzite bands define intrafolial folds; the gneissosity of the host khondalite is axial planar to these folds and is therefore termed $S_{1}$.

Charnockite occurs as massif-type bodies characterised by the presence of pervasive, but streaky, gneissic foliation. The charnockite hosts the bands and patches of other varieties of pyroxene-bearing granulites. The hornblende-granulite mostly occurs as bands, also as discordant patches, as well as folded layers, with gneissic foliation of the enclosing charnockite axial planar to these folds. The enderbite and two-pyroxene granulite occur as small lenticular patches, disposed along the foliation of the host charnockite. Such a mode of occurrence of these members of the pyroxene-bearing granulites indicates that they may be genetically connected. Kar et al (2003) documented that the massiftype charnockite is a tonalitic magma, product of hornblende-dehydration melting in the protolith of hornblende-granulite; the hornblende-granulite occurring as xenolith in it.

\subsection{Structural setting}

Three phases of folding are recognised from the granulite complex of the area (Kar 1995). Quartzite bands in the khondalite host and hornblendegranulite bands in the massif-type charnockite host define the intrafolial, reclined $\mathrm{F}_{1}$ folds. The pervasive gneissic banding of the khondalite and streaky gneissic foliation of the charnockite-massif are axial planar to these minor $\mathrm{F}_{1}$ folds, and are designated as $\mathrm{S}_{1} \cdot \mathrm{F}_{2}$ folds are commonly tight, and have axial planar foliation, defined by alignment of ribbon-shaped and platy quartz, plattung structure, known as leptynitic foliation after Sen (1987), and designated $\mathrm{S}_{2}$. These $\mathrm{F}_{2}$ folds occur on regional scale and determine the map-pattern of the area (figure 1). $\mathrm{F}_{3}$ folds are regional broad warps, developed on regionally parallel $S_{1} / S_{2}$ fabrics. Notably, $\mathrm{S}_{1}$ and $\mathrm{S}_{2}$ foliations also dominate both the lithologies at limbs and noses of regional $\mathrm{F}_{2}$ folds respectively. Also, overprinting of the $\mathrm{S}_{1}$ foliation by $\mathrm{S}_{2}$ foliation and complete obliteration of the earlier foliation at places are commonly observed.

The $\mathrm{F}_{1}-\mathrm{F}_{2}$ folds generate both hook-shaped and arrowhead shaped interference pattern on profile section on outcrop scale. The form surface of these refolded folds is represented by a quartzite band in the khondalite host and horblende-granulite band in the charnockite host. Kar (1999, 2001) described the regional fold geometry and detailed structural analysis of the area, which reveals that the regional geometry could be the result of a break in the deformation history. Also, the $\mathrm{S}_{2}$ foliation often crosscuts the $S_{1}$ foliation at the noses of the regional $F_{2}$ folds and the transposition of $S_{1}$ by $\mathrm{S}_{2}$ at places certainly attesting to this break.

\subsection{Microstructures}

The two prime lithologies of the area, khondalite and charnockite preserve two deformation fabrics, $\mathrm{S}_{1}$ and $\mathrm{S}_{2}$, on hand-specimen scale also.

\subsection{1 $S_{1}$ fabric}

Garnet-ilmenite-sillimanite segregations define the $\mathrm{S}_{1}$ gneissic banding in the khondalite. Two domains are readily identifiable, felsic domains and mafic domains. In the felsic domains, evidence of crystal plastic deformation is very clear within quartz and feldspar. Large quartz grains often show undulose extinction and deformation banding; occasional subgrains are also observed. Although xenoblastic texture is apparent, close scrutiny reveals an aggregate of relatively coarse-grained quartz, having irregular grain boundaries; commonly interpreted to be the product of grain boundary migration (GBM) recrystallisation (Passchier and Trouw 1996). Moreover, typical granoblastic textures are observed at places, possibly a product of static recrystallisation. In the mafic domains, on the other hand, garnet porphyroblasts are generally undeformed. Ilmenite and sillimanite grains sometimes show wavy foliation; the fairly coarse tabular crystals of sillimanite show optical discontinuity.

Lenticular accumulations of orthopyroxene, plagioclase and $\mathrm{Fe}-\mathrm{Ti}$-Oxides within a quartz-feldspar groundmass define the $S_{1}$ streaky gneissic foliation in the charnockite. Two domainal divisions, namely, lenticular mafic domains and felsic domains could be identified on microscopic scale. 
The felsic domains are characterised by typical granoblastic texture with triple point contacts of coexisting mineral phases. Signatures of crystal plastic deformation are preserved in large grains: undulose extinction and occasional sub-grain formation in quartz and bending of twin lamellae in plagioclase. In the mafic domains, on the other hand, recrystallisation of fine moats of orthopyroxene along the margin of the large orthopyroxene grains is indicative of high temperature recrystallisation (Passchier and Trouw 1996). Also, exsolution lamellae of clinopyroxene in the host orthopyroxene are suggestive of the possibility of high temperature microstructural readjustment (Passchier and Trouw 1996).

\subsection{2 $S_{2}$ fabric}

At $\mathrm{F}_{2}$ fold noses, $\mathrm{S}_{1}$ gneissosity is virtually obliterated. The $S_{2}$ fabric in the khondalite is defined by arrangement of plates of quartz. Relatively fine-grained, polycrystalline and lenticular quartz with irregular grain boundaries define the $\mathrm{S}_{2}$ fabric, which is interpreted to be the result of subgrain rotation (SR) recrystallisation (Passchier and Trouw 1996). Static recrystallisation on this resulted in the platy granoblastic textures. This is the microscopic manifestation of the typical plattung structure (Merh 1962; Sen 1987), the so-called leptynitic foliation. The garnet porphyroblasts are generally deformed and occasionally show sigmoidal grain shapes with tapering ends. Also, the sillimanite and feldspars show sigmoidal grain shapes. The tapering ends of these sigmoidal porphyroblasts commonly form an acute angle with the characteristic leptynitic foliation, indicating deformation-induced growth of the porphyroblasts.

In the charnockite polycrystalline, relatively fine-grained and lenticular quartz-feldspar aggregates with irregular grain boundaries define the $\mathrm{S}_{2}$ fabric. In extreme cases, this dynamic recrystallisation finally resulted in the formation of a mylonitic foliation. Sigmoidal orthopyroxene is also present.

Locally, in the felsic bands of the enderbite and two-pyroxene granulite typical platy granoblastic texture is common. This microstructural readjustment might have been related to the event responsible for the development of the $\mathrm{S}_{2}$ fabric. Notably, hornblende-granulites never contain platy granoblastic texture. Mafic rich lithologies in them might have hindered such microstructural readjustment.

Thus the deformational regime and/or response during the development of $\mathrm{S}_{1}$ and $\mathrm{S}_{2}$ fabric in the similar lithologies might have been different. Simple shear component during the development of $\mathrm{S}_{2}$ fabric was much higher. To summarize, structurally

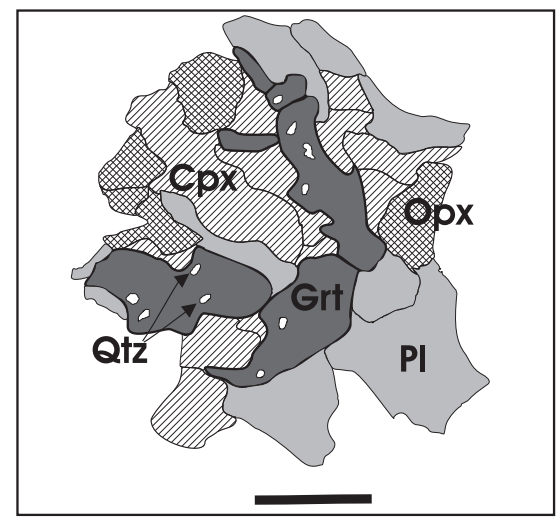

Figure 2. Sketch from photomicrograph showing garnet moat with occasional dactylitic quartz, separating clinopyroxene and plagioclase in hornblende-granulite. Scale bar: $5 \mu$.

there is convincing microstructural evidence for $S_{1}$ and $\mathrm{S}_{2}$, both characterised by high $\mathrm{T}$ minerals and with $\mathrm{S}_{2}$ at an angle to $\mathrm{S}_{1}$. Also, almost complete obliteration of previous deformation fabric $\left(\mathrm{S}_{1}\right)$ and growth of new fabric $\left(\mathrm{S}_{2}\right)$ having distinct characteristic features indicate annealing during the latter fabric development.

\section{Petrography}

\subsection{Mineral assemblages}

Khondalite is characterised by the assemblage: quartz $(60 \%)$ - K-feldspar $(5 \%)$ - garnet $(25 \%)-$ sillimanite $(5 \%)$ - ilmenite $(4 \%)$ - rutile $(1 \%)$ \pm biotite. Notably, significant secondary biotite development, after garnet, is generally noticed in the samples having dominant $\mathrm{S}_{2}$-fabric. The members of the pyroxene-bearing granulites are characterised by the following primary assemblages. Charnockite: plagioclase (35\%) - quartz (25\%) K-feldspar (25\%) - orthopyroxene (10\%) - Fe-Ti oxides $(5 \%) \pm$ garnet \pm clinopyroxene \pm hornblende \pm biotite; hornblende-granulite: hornblende $(35 \%)$ - clinopyroxene (20\%) - orthopyroxene $(15 \%)$ - plagioclase $(27 \%)$ - quartz $(2 \%) \pm$ garnet; two-pyroxene granulite: clinopyroxene $(30 \%)-$ orthopyroxene $(25 \%)$ - plagioclase $(30 \%)-\mathrm{Fe}-\mathrm{Ti}$ oxides $(5 \%)$ - quartz (8\%) - K-feldspar $(2 \%) \pm$ garnet \pm hornblende \pm biotite; enderbite: plagioclase $(35 \%)$ - orthopyroxene $(20 \%)$ - K-feldspar $(17 \%)$ - quartz (15\%) - clinopyroxene $(13 \%) \pm$ garnet $\pm \mathrm{Fe}-\mathrm{Ti}$ oxides \pm hornblende \pm biotite. Garnet, although one of the major mineral phases in all these lithologies, invariably preserves reaction relations, mostly rimming the pyroxenes or forming coronas on them (figures 2, 3 and 4). In some samples, garnet porphyroblasts are observed 


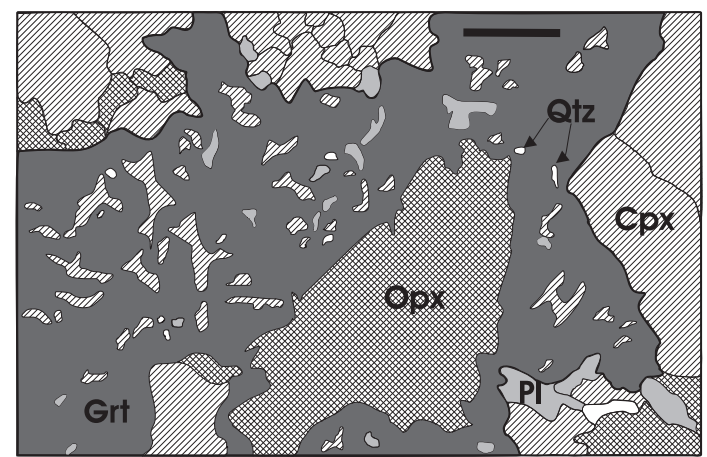

Figure 3. Sketch from photomicrograph showing garnetclinopyroxene-quartz intergrowth enclosing orthopyroxene with embayed grain boundaries in hornblende-granulite; note plagioclase inclusion within the intergrowth. Scale bar: $5 \mu$.

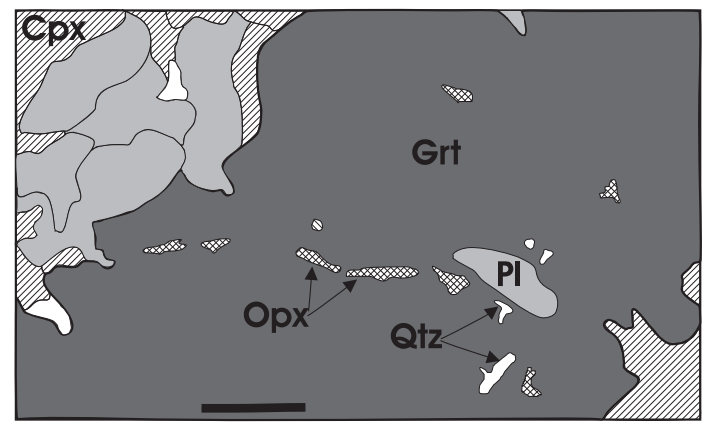

Figure 4. Sketch from photomicrograph showing xenoblastic garnet with inclusions of orthopyroxene and plagioclase in two-pyroxene granulite. Scale bar: $5 \mu$.

enclosing the pyroxene and plagioclase. Pyroxenes in the two-pyroxene granulite assemblage occur in two distinct modes, one as inclusions within garnet and the other as matrix phases. Notably, they are compositionally distinct (section on mineral chemistry). Also, the abundant secondary growth of hornblende and biotite after pyroxenes is more pronounced in the samples with dominant $\mathrm{S}_{2}$-fabric.

\section{Mineral chemistry}

\subsection{Analytical data}

Mineral chemical data are obtained through Electron Probe Micro Analysis. EPMA work was carried out at the University Science Instrumentation Centre of Roorkee University and National Geophysical Research Institute, Hyderabad, using Jeol Jxa-8600M and Philips Camebax Microprobe Machine respectively. Operating conditions at Roorkee was $15 \mathrm{kV}$ accelerating voltage, $0.5 \mathrm{nA}$ sample current and $3 \mu \mathrm{m}$ beam diameter, while those at Hyderabad were $15 \mathrm{kV}$ and $20 \mathrm{kV}$ accelerating voltage, $0.5 \mathrm{nA}$ sample current and $2 \mu \mathrm{m}$ beam diameter. A few analyses were obtained from Yokohama National University, Japan using JEOL JSM-5300 electron microprobe and LINK QX2000J system (operating at $15 \mathrm{kV}$ and $0.5 \mathrm{nA}$ sample current).

\subsection{Garnet}

Mineral compositions of the garnet are presented in table $1 . \mathrm{S}_{1}$-garnets in the khondalite are almandine rich; $X_{\mathrm{Gr}}$ and $X_{\mathrm{Sp}}$ are insignificant. No compositional zoning is observed. However, some porphyroblasts show a marginal magnesian depletion towards the rim (sample no. 2/J96A, core: $\mathrm{Py}_{18}$ and rim: $\left.\mathrm{Py}_{16}\right)$. $\mathrm{S}_{2}$-garnets are relatively magnesium rich (sample no. 2/J96B, $\mathrm{Alm}_{76} \mathrm{Py}_{21}$ ), although some relatively less magnesian garnet are also present along the $S_{2}$ fabric; these may represent relict $\mathrm{S}_{1}$-garnet. Notably, garnet overgrowths are more magnesian than idioblastic core (sample no. 2/J78A, core: $\mathrm{Py}_{17} \mathrm{Alm}_{78}$ and overgrowth: $\mathrm{Py}_{20} \mathrm{Alm}_{74}$ ).

Garnets in the hornblende-granulite are nearly homogeneous in composition, containing 54-55\% almandine, $24-25 \%$ pyrope, $15-17 \%$ grossular, but slightly variable from sample to sample. Significantly, no marked distinction in composition is noticed when it rims different phases like orthopyroxene and clinopyroxene; although slight magnesium depletion towards rims in relatively thicker coronas is noticeable.

$\mathrm{S}_{1}$-garnets of two-pyroxene granulites are generally homogeneous, although markedly different from sample to sample. However, some large porphyroblasts show subtle iron enrichment towards the rim (core: $\mathrm{Py}_{34} \mathrm{Alm}_{48} \mathrm{And}_{1} \mathrm{Gr}_{15}$ and rim: $\left.\mathrm{Py}_{33} \mathrm{Alm}_{49} \mathrm{And}_{5} \mathrm{Gr}_{12}\right)$. On the other hand, $\mathrm{S}_{2}$-garnets are less magnesian but homogeneous with $57-58 \%$ almandine, $21-23 \%$ pyrope and $15-$ $18 \%$ grossular contents. The most noticeable feature is the marginal subtle magnesium enrichment in thicker coronas, unlike the other coronal garnets in $\mathrm{S}_{1}$ dominated hornblende-granulite and two pyroxene-granulites.

\subsection{Pyroxene}

Mineral chemistry of pyroxenes is presented in table 2. Clinopyroxenes of the hornblende-granulite are basically augites with low jadeite-acmite components (maximum $3.6 \mathrm{~mol} . \%$ ) and insignificant octahedral Al (maximum 0.05). However, in some samples the clinopyroxenes have quite higher jadeite-acmite component (maximum 5.4 mol.\%) and markedly high octahedral $\mathrm{Al}$ contents (0.09 


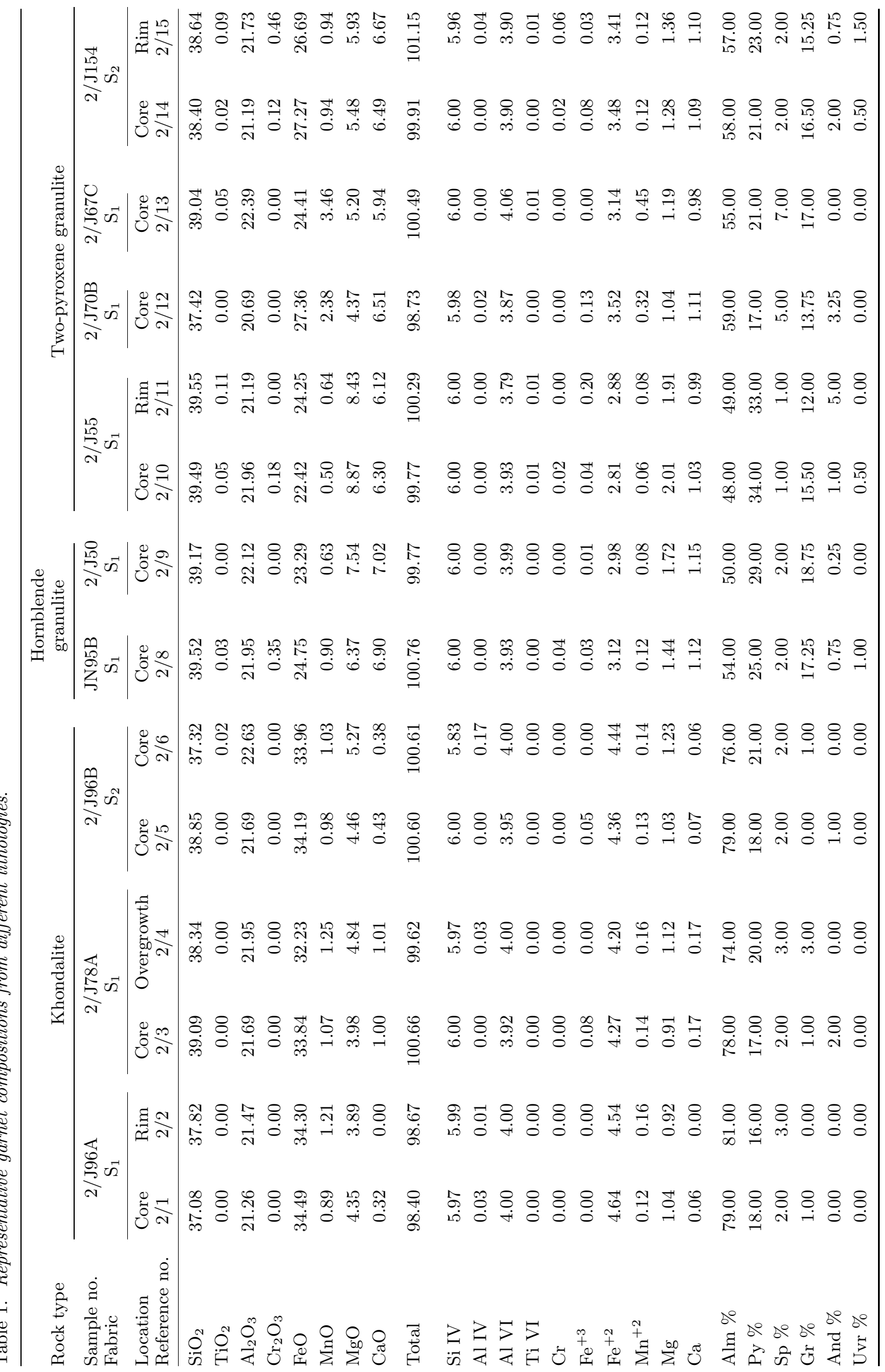




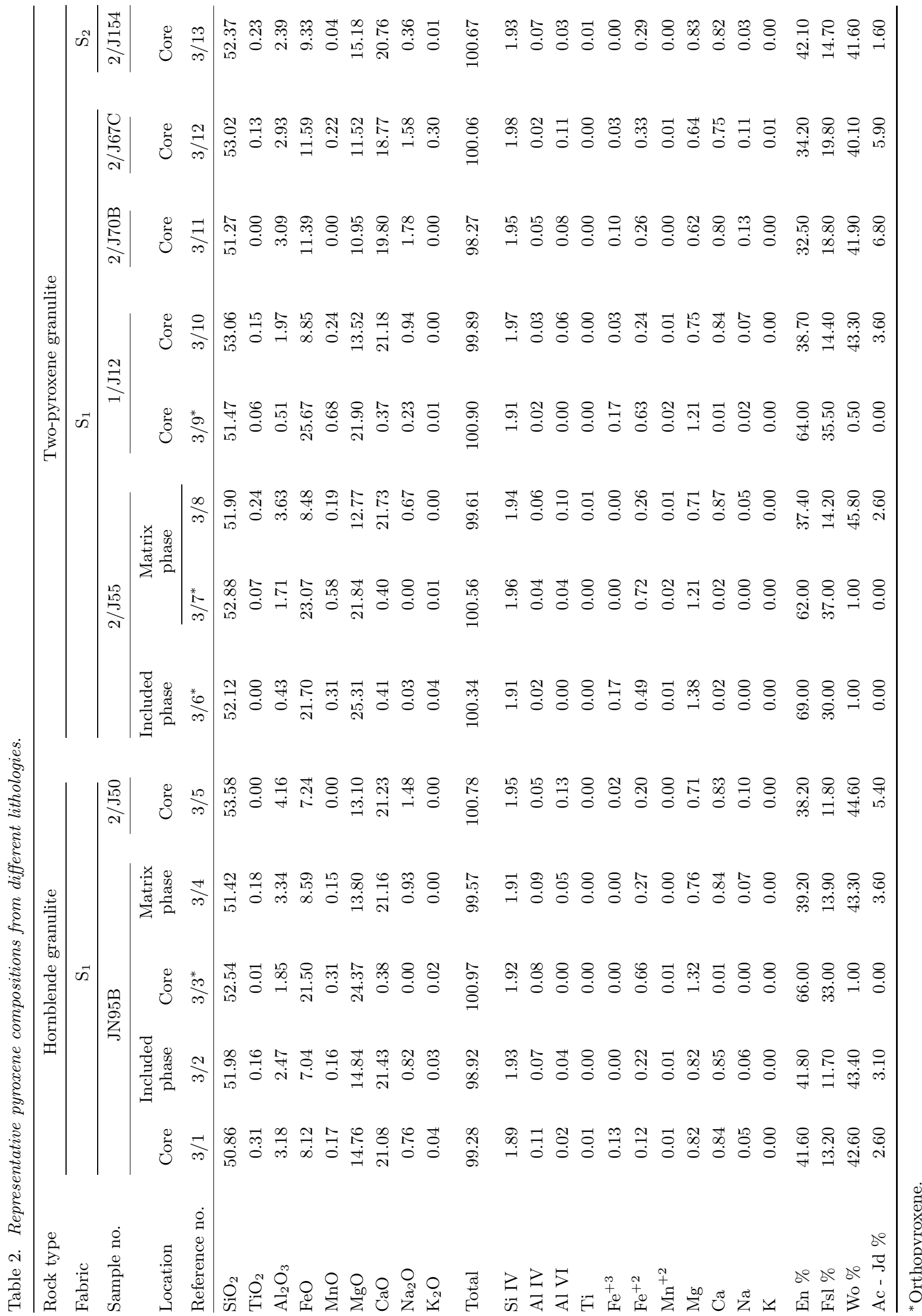


to 0.13 ). This sample (no. $2 / \mathrm{J} 50$ ) is orthopyroxenefree and has euhedral garnet. Interestingly, clinopyroxene included in garnet and as matrix phase are markedly different in composition, the matrix phase being more iron rich (sample no. JN95B, included phase: $\mathrm{En}_{42} \mathrm{Fsl}_{11} \mathrm{Wo}_{43}$ and matrix phase: $\left.\mathrm{En}_{39} \mathrm{Fsl}_{14} \mathrm{Wo}_{43}\right)$. Orthopyroxenes are typically hypersthene with $66 \mathrm{~mol} . \%$ of enstatite with very low $\mathrm{Al}_{2} \mathrm{O}_{3}$ content (up to 1.85 wt.\%).

The $\mathrm{S}_{1}$-clinopyroxenes in the two-pyroxene granulite are also augites. Marked compositional difference is noticed from sample to sample, especially in terms of jadeite-acmite contents and octahedral aluminium contents. Two groups are noticed, one having relatively high jadeite-acmite component and octahedral Al contents (maximum $6.8 \mathrm{~mol} . \%$ and 0.12 respectively) compared to the other (Jd-Ac: maximum $3.6 \mathrm{~mol} . \%$ and octahedral $\mathrm{Al}$ : 0.06). Orthopyroxenes are hypersthenes with slight variation in composition from sample to sample. Octahedral $\mathrm{Al}$ content is very low, varying between 0.02 and 0.04 . The orthopyroxene occurring as an included phase within garnet is more magnesian than matrix one (sample no. 2/J55, included phase: $\mathrm{En}_{69} \mathrm{Fsl}_{30}$ and matrix phase: $\left.\mathrm{En}_{62} \mathrm{Fsl}_{37}\right) . \mathrm{S}_{2^{-}}$ Clinopyroxene in the two-pyroxene granulites is also a solid solution of diopside-hedenbergite and contains low jadeite $(1.6 \mathrm{~mol} . \%)$ and octahedral $\mathrm{Al}$ (0.07).

\subsection{Ilmenite}

Ilmenite in both the $\mathrm{S}_{1}$ and $\mathrm{S}_{2}$ dominated samples of khondalite are almost pure variety; $X_{\text {Ilmenite }}$ is 98-99 mol.\%. However, a slight variation of composition is also noticed; the included ilmenite in garnet is marginally less magnesian (table 3 ).

\subsection{Feldspar}

Plagioclase feldspars of hornblende-granulite are mostly oligoclase-andesine variety with $29-32 \%$ of anorthite. On the other hand, the plagioclases of two-pyroxene granulites are strictly andesine and are fairly rich in anorthite content: $36-38 \%$ (table 4).

\section{$4.6 K_{D}$ values}

$K_{D}$ values are provided in table 5 . In hornblendegranulite, $K_{D}^{\mathrm{Cpx}-\mathrm{Grt}}\left[(\mathrm{Fe} / \mathrm{Mg})^{\mathrm{Cpx}} /(\mathrm{Fe} / \mathrm{Mg})^{\mathrm{Grt}}\right]$ values of six coexisting pairs vary within a short range (0.15-0.19). The rim compositions for the same pairs show either similar or marginally lower $K_{D}$ values. Coexisting pyroxenes have high $K_{D}^{\mathrm{Cpx}-\mathrm{Opx}}$ $\left[(\mathrm{Fe} / \mathrm{Mg})^{\mathrm{Cpx}} /(\mathrm{Fe} / \mathrm{Mg})^{\mathrm{Opx}}\right]$ value, 0.71, indicating a high temperature record.
Table 3. Representative ilmenite compositions from khondalite.

\begin{tabular}{|c|c|c|c|}
\hline \multirow{3}{*}{$\begin{array}{l}\text { Fabric } \\
\text { Sample no. } \\
\text { Location } \\
\text { Reference no. }\end{array}$} & \multirow{3}{*}{ 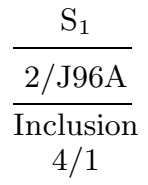 } & \multirow{2}{*}{\multicolumn{2}{|c|}{$\frac{\mathrm{S}_{2}}{2 / \mathrm{J} 96 \mathrm{~B}}$}} \\
\hline & & & \\
\hline & & $\begin{array}{c}\text { Inclusion } \\
4 / 2\end{array}$ & $\begin{array}{c}\text { Matrix } \\
4 / 3\end{array}$ \\
\hline $\mathrm{SiO}_{2}$ & 0.42 & 0.04 & 0.01 \\
\hline $\mathrm{TiO}_{2}$ & 52.76 & 49.94 & 49.36 \\
\hline $\mathrm{Al}_{2} \mathrm{O}_{3}$ & 0.00 & 0.00 & 0.00 \\
\hline $\mathrm{Cr}_{2} \mathrm{O}_{3}$ & 0.00 & 0.06 & 0.06 \\
\hline $\mathrm{FeO}$ & 44.69 & 49.27 & 48.96 \\
\hline $\mathrm{MnO}$ & 0.00 & 0.37 & 0.10 \\
\hline $\mathrm{MgO}$ & 0.50 & 0.00 & 0.99 \\
\hline $\mathrm{CaO}$ & 0.00 & 0.00 & 0.00 \\
\hline Total & 98.37 & 99.68 & 99.48 \\
\hline $\mathrm{Si}$ & 0.01 & 0.00 & 0.00 \\
\hline $\mathrm{Ti}$ & 1.01 & 0.95 & 0.93 \\
\hline $\mathrm{Al}$ & 0.00 & 0.00 & 0.00 \\
\hline $\mathrm{Cr}$ & 0.00 & 0.00 & 0.00 \\
\hline $\mathrm{Fe}^{+3}$ & 0.00 & 0.10 & 0.13 \\
\hline $\mathrm{Fe}^{+2}$ & 1.01 & 0.94 & 0.89 \\
\hline $\mathrm{Mn}$ & 0.00 & 0.01 & 0.00 \\
\hline $\mathrm{Mg}$ & 0.02 & 0.00 & 0.04 \\
\hline $\mathrm{Ca}$ & 0.00 & 0.00 & 0.00 \\
\hline Ilmenite $\%$ & 98.00 & 99.00 & 96.00 \\
\hline Geikelite \% & 2.00 & 0.00 & 3.00 \\
\hline Phanite \% & 0.00 & 1.00 & 1.00 \\
\hline
\end{tabular}

In two-pyroxene granulite, $K_{D}$ values of two spatially separated clinopyroxene-orthopyroxene pairs are also high (0.62 and 0.69) in one sample (no. 2/J55), thereby suggesting a high temperature signature. In another sample $(1 / \mathrm{J} 12)$, two orthopyroxene-clinopyroxene pairs register lower $K_{D}$ values, 0.58 and 0.54 , for the core-core and rim-rim compositions. Notably, the latter samples are more magnesian (\#Mg no. 62) than the former (\#Mg no. 55), thereby conclusively indicating the temperature dependence of the $K_{D}$ values. $K_{D}^{\mathrm{Cpx}-\mathrm{Grt}}$ values for the core compositions are almost constant (0.15-0.17) with marginal changes towards the rim. In another sample, three coexisting but spatially separated clinopyroxene-garnet pairs show similar $K_{D}$ values $(0.14,0.15,0.19)$ for the core compositions. Coronal garnet on clinopyroxene, records higher $K_{D}$ value (0.16) for composition of the points away from the contact than that of the points near the contact (0.11), thereby indicating substantial cooling. 
Table 4. Representative plagioclase composition from different lithologies.

\begin{tabular}{|c|c|c|c|c|}
\hline \multirow{4}{*}{$\begin{array}{l}\text { Rock type } \\
\text { Fabric } \\
\text { Sample no. } \\
\text { Location } \\
\text { Reference no. }\end{array}$} & \multirow{2}{*}{\multicolumn{2}{|c|}{$\begin{array}{c}\text { Hornblende-granulite } \\
\mathrm{S}_{1} \\
\text { JN95B }\end{array}$}} & \multicolumn{2}{|c|}{ Two-pyroxene granulite } \\
\hline & & & \multirow{3}{*}{$\begin{array}{c}\mathrm{S}_{1} \\
2 / \mathrm{J} 55 \\
\begin{array}{c}\text { Inclusion } \\
5 / 3\end{array}\end{array}$} & \multirow{3}{*}{$\begin{array}{c}\mathrm{S}_{2} \\
2 / \mathrm{J} 154 \\
\text { Inclusion } \\
5 / 4\end{array}$} \\
\hline & Inclusion & Inclusion & & \\
\hline & $5 / 1$ & $5 / 2$ & & \\
\hline $\mathrm{SiO}_{2}$ & 61.64 & 62.23 & 60.68 & 59.90 \\
\hline $\mathrm{Al}_{2} \mathrm{O}_{3}$ & 24.63 & 25.38 & 25.25 & 25.50 \\
\hline $\mathrm{CaO}$ & 6.19 & 5.87 & 6.90 & 7.38 \\
\hline $\mathrm{Na}_{2} \mathrm{O}$ & 7.24 & 7.53 & 6.40 & 6.51 \\
\hline $\mathrm{K}_{2} \mathrm{O}$ & 0.26 & 0.33 & 0.25 & 0.22 \\
\hline Total & 99.95 & 101.34 & 99.47 & 99.51 \\
\hline $\mathrm{Si}$ & 2.76 & 2.74 & 2.74 & 2.70 \\
\hline $\mathrm{Al}$ & 1.30 & 1.32 & 1.35 & 1.36 \\
\hline $\mathrm{Ca}$ & 0.30 & 0.28 & 0.33 & 0.36 \\
\hline $\mathrm{Na}$ & 0.63 & 0.64 & 0.56 & 0.57 \\
\hline K & 0.02 & 0.02 & 0.02 & 0.01 \\
\hline Anorthite \% & 32.00 & 29.50 & 36.70 & 38.00 \\
\hline Albite $\%$ & 67.00 & 68.50 & 61.70 & 60.60 \\
\hline Orthoclase \% & 1.00 & 2.00 & 1.60 & 1.40 \\
\hline
\end{tabular}

Table $5 . K_{D}$ values of different co-existing mineral phases.

\begin{tabular}{|c|c|c|c|c|c|c|}
\hline \multirow[b]{2}{*}{ Rock type } & \multirow{2}{*}{$\begin{array}{l}\text { Sample no. } \\
\quad(\text { fabric })\end{array}$} & \multirow[b]{2}{*}{ Pair no. } & \multicolumn{2}{|c|}{$K_{D}(\mathrm{Cpx}-\mathrm{Opx})$} & \multicolumn{2}{|c|}{$K_{D}(\mathrm{Cpx}-\mathrm{Grt})$} \\
\hline & & & Core-core & Rim-rim & Core-core & Rim-rim \\
\hline \multirow{7}{*}{$\begin{array}{l}\text { Hornblende- } \\
\text { granulite }\end{array}$} & JN95B $\left(\mathrm{S}_{1}\right)$ & Co-existing pair 1 & 0.71 & & & \\
\hline & $2 / \mathrm{J} 50\left(\mathrm{~S}_{1}\right)$ & Co-existing pair 1 & & & 0.18 & 0.18 \\
\hline & & Co-existing pair 2 & & & 0.18 & 0.16 \\
\hline & & Co-existing pair 3 & & & 0.15 & 0.15 \\
\hline & & Co-existing pair 4 & & & 0.19 & 0.19 \\
\hline & & Co-existing pair $5^{*}$ & & & 0.18 & 0.15 \\
\hline & & Co-existing pair 6 & & & 0.16 & 0.15 \\
\hline \multirow{13}{*}{$\begin{array}{l}\text { Two-pyroxene } \\
\text { granulite }\end{array}$} & $2 / \mathrm{J} 55\left(\mathrm{~S}_{1}\right)$ & Co-existing pair 1 & 0.57 & & & \\
\hline & & Co-existing pair 2 & 0.62 & & & \\
\hline & & Co-existing pair 3 & 0.69 & & & \\
\hline & $1 / \mathrm{J} 12\left(\mathrm{~S}_{1}\right)$ & Co-existing pair 1 & 0.58 & 0.57 & & \\
\hline & & Co-existing pair 2 & 0.54 & 0.57 & & \\
\hline & $2 / \mathrm{J} 70 \mathrm{~B}\left(\mathrm{~S}_{1}\right)$ & Coronal garnet* & & & 0.16 & 0.11 \\
\hline & & Co-existing pair 1 & & & 0.16 & 0.15 \\
\hline & & Co-existing pair 2 & & & 0.17 & 0.18 \\
\hline & & Co-existing pair 3 & & & 0.15 & 0.15 \\
\hline & & Co-existing pair 1 & & & & \\
\hline & $2 / \mathrm{J} 67 \mathrm{C}\left(\mathrm{S}_{1}\right)$ & Co-existing pair 1 & & & 0.14 & \\
\hline & & Co-existing pair $2^{*}$ & & & 0.19 & 0.16 \\
\hline & & Co-existing pair 3 & & & 0.15 & 0.16 \\
\hline
\end{tabular}

${ }^{*} P, T$ estimates of these mineral pairs are provided in table 6 . 


\section{Reaction textures and metamorphic reactions}

\section{$5.1 S_{1}$-microdomains}

$\mathrm{S}_{1}$-garnet porphyroblasts in khondalite generally contain inclusion trails of sillimanite and/or ilmenite and/or quartz, indicating their appearance from an early ilmenite-sillimanite-quartz assemblage.

$$
\begin{aligned}
& {\text { sillimanite }+ \text { ilmenite }_{98}+\text { quartz }}^{\rightarrow \text { almandine }_{79}+\text { rutile. }}
\end{aligned}
$$

Common garnet-quartz symplectite with inclusions of clinopyroxene and plagioclase in hornblende-granulite is suggestive of the reaction

$$
\text { diopside }_{60}+\text { anorthite }_{32} \rightarrow \text { pyrope }_{25}+\text { quartz. }
$$

Garnet moats separating clinopyroxene and plagioclase (figure 2) also support this reaction.

The intergrowth texture involving garnet, clinopyroxene and quartz enclosing relict orthopyroxene and plagioclase (figure 3 ), possibly indicates a reaction of the type:

$$
\begin{aligned}
& \text { enstatite }_{66}+\text { anorthite }_{29} \\
& \quad \rightarrow \text { pyrope }_{25}+\text { diopside }_{61}+\text { quartz. }
\end{aligned}
$$

Notably, Harley (1989) pointed out the possibility of this reaction from quartz bearing mafic granulites. Dasgupta et al (1991) also noted this reaction from the mafic granulites of the Eastern Ghats belt.

Xenoblastic garnet in two-pyroxene granulite with inclusion of orthopyroxene and plagioclase is frequently noticed (figure 4), and this is suggestive of the reaction:

$$
\text { enstatite }_{69}+\text { anorthite }_{37} \rightarrow \text { pyrope }_{33}+\text { quartz. }
$$

As the matrix also contains the included phases, especially orthopyroxene, the definite indicator of this reaction should be their compositional difference (Vernon 1996); the matrix phase here is less magnesian $\left(\mathrm{En}_{62}\right)$. Also, inclusion-free coronal garnet occurs on clinopyroxene, definitely suggesting their formation on cooling.

\section{$5.2 S_{2}$-microdomains}

Although $\mathrm{S}_{2}$-garnet porphyroblasts with inclusion trails are rare, the commonly observed reaction texture is the relict sillimanite-ilmenite association separated from quartz by garnet, and

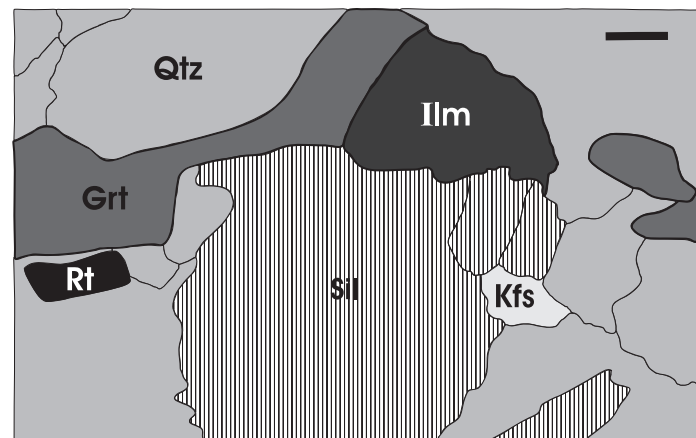

Figure 5. Sketch from photomicrograph showing neoblastic garnet separating sillimanite-ilmenite association from quartz in khondalite; note presence of rutile in the vicinity. Scale bar: $10 \mu$.

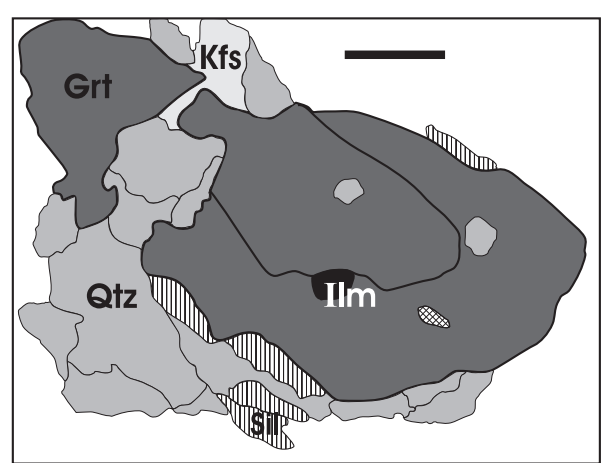

Figure 6. Sketch from photomicrograph showing garnet overgrowth on early euhedral garnet in khondalite. The early garnet is less magnesian $\left(\mathrm{Py}_{17}\right)$ than overgrowth $\left(\mathrm{Py}_{20}\right)$. Scale bar: $5 \mu$.

occurrence of rutile in the vicinity (figure 5), indicating that the garnet is mostly the product of reaction:

$$
\begin{aligned}
& \text { sillimanite }+ \text { ilmenite }_{96}+\text { quartz } \\
& \rightarrow \text { almandine }_{76}+\text { rutile },
\end{aligned}
$$

similar to reaction (1), but with different compositions.

The development of garnet overgrowth on early idioblastic garnet (figure 6), is consistent with this later garnet growth. The euhedral core is relict porphyroblast and is less magnesian $\left(\mathrm{Py}_{17} \mathrm{Alm}_{78}-\right.$ against $\mathrm{Py}_{20} \mathrm{Alm}_{74}$ of the overgrowth).

Most of the $\mathrm{S}_{2}$-garnet xenoblast in two-pyroxene granulite contains inclusion of clinopyroxene and plagioclase (figure 7), which is suggestive of the garnet forming reaction:

$$
\text { diopside }_{59}+\text { anorhtite }_{38} \rightarrow \text { pyrope }_{21}+\text { quartz, (6) }
$$

similar to reaction (2), but with different compositions. 


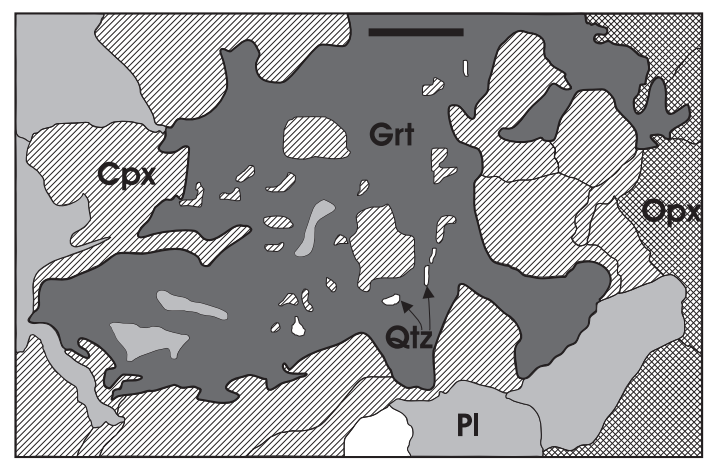

Figure 7. Sketch from photomicrograph showing garnet xenoblast with inclusions of clinopyroxene and plagioclase in two-pyroxene granulite. Scale bar: $5 \mu$.

The enhanced degree of reaction and new garnet formation in $\mathrm{S}_{2}$ is a consequence of moving to lower $T-P$ with increasing facilitation of reaction. The equilibrations are at least divariant. Notably, the aluminosilicates in the $\mathrm{S}_{2}$ samples are more abundant, thereby suggesting relative lower temperature of the assemblage, although garnet breakdown reaction is not noticed.

\section{Metamorphic evolution}

Thermometric and barometric calculations have been made using TWEEQU (Berman 1991) approach. Berman (1991) has shown that with the proper choice of solution models, this technique may estimate temperature and pressure with uncertainties less than $\pm 40^{\circ} \mathrm{C}$ and less than \pm 0.5 kbar respectively. Thermodynamic parameters of different minerals are taken from the internally consistent data set of Berman (1988 and updated database of 1992). Additionally, the activities of the mineral phases like quartz, rutile, sillimanite are taken to be unity (assumed to be pure phase).

For precise thermobarometric analysis, a proper choice of solution model for interacting phases is necessary. For garnet, the quaternary solid solution of Berman (1990) is adopted as the garnets of the present assemblages contain fairly high grossular contents. For plagioclase, the solution model of Fuhrman and Lindsley (1988) is used in view of the high anorthite content of the plagioclase. For pyroxenes, the ideal on-site solution model is adopted here as inconsistent results are reported by Bhattacharya et al (1991) and Bhattacharya et al (1993) when using binary solution models of Wood and Banno (1973). Further, Bhattacharya et al (1993) also noted that the internally consistent database, used here, does not fit to the solution model of Wood and Banno (1973).

\section{$6.1 P-T$ record}

\subsection{1 $S_{1}$ dominated samples}

No independent $\mathrm{Fe}-\mathrm{Mg}$ exchange thermometer is available for the khondalites, due to the absence of suitable $\mathrm{Fe}-\mathrm{Mg}$ phase other than garnet. However, good barometry is available from the garnet-ilmenite-rutile-sillimanite-quartz assemblage (GRAIL). The GRAIL barometer yields a pressure estimate of $8.5 \mathrm{kbar}$, estimated from reaction (1) at a temperature of $850^{\circ} \mathrm{C}$ (table 6).

In the hornblende-granulites, coexisting pyroxene pairs yield temperatures of the order of $950^{\circ} \mathrm{C}$. Six pairs of coexisting clinopyroxene-garnet yield temperatures between $660^{\circ} \mathrm{C}$ and $800^{\circ} \mathrm{C}$. Garnet moats separating clinopyroxene and plagioclase, indicating reaction (2), register a variation of temperature between $740^{\circ} \mathrm{C}$ and $640^{\circ} \mathrm{C}$ at $8.6 \mathrm{kbar}$ for the core and rim compositions respectively. Formation of garnet-clinopyroxenequartz symplectites from orthopyroxene and plagioclase, indicating reaction (3), is estimated to have occurred at $9 \mathrm{kbar}, 770^{\circ} \mathrm{C}$ (table 6). The peak $P-T$ conditions retrieved from the sample no. JN95B using the convergence method is given by the intersection of $\mathrm{Opx}-\mathrm{Cpx}$ thermometer and GOPCQ barometer as $950^{\circ} \mathrm{C}$ and $9.0 \mathrm{kbar}$.

The highest temperatures of the order of $900^{\circ} \mathrm{C}$ and $800^{\circ} \mathrm{C}$ are recorded from two-pyroxene granulite, using coexisting orthopyroxene-clinopyroxene pairs. On the other hand, coexisting garnet-clinopyroxene pairs yield temperatures in the range of $750^{\circ} \mathrm{C}-800^{\circ} \mathrm{C}$ and $650^{\circ} \mathrm{C}-800^{\circ} \mathrm{C}$ in different samples. However, coronal garnet on clinopyroxene yields temperatures of $800^{\circ} \mathrm{C}$ and $600^{\circ} \mathrm{C}$ from the points away from the contact and points adjacent to the contact respectively; thus a $200^{\circ} \mathrm{C}$ cooling is indicated. The different estimated temperatures for different coexisting pairs might thus represent 'frozen' temperatures of microdomains (Frost and Chacko 1989).

Garnet - orthopyroxene - plagioclase - quartz (GOPQ) barometry applied to a garnetbearing two-pyroxene granulite yields pressure estimate $9.5 \pm 0.5 \mathrm{kbar}$, consistent with garnetclinopyroxene-plagioclase-quartz (GCPQ) barometry of $8.9 \pm 0.5 \mathrm{kbar}$ on the same sample. The peak $P-T$ conditions retrieved from the sample no. 2/J55 using the convergence method is given by the intersection of $\mathrm{Opx}-\mathrm{Cpx}$ thermometer and GOPQ barometer as $900^{\circ} \mathrm{C}$ and 9.5 kbar.

\subsection{2 $S_{2}$ dominated samples}

The GRAIL barometer, applied in garnet forming reaction (5), yields a pressure values of 
Table 6. P-T estimates from different rocks.

\begin{tabular}{|c|c|c|c|c|c|}
\hline Rock type & Sample no./fabric & Thermometer & Location & & $T\left({ }^{\circ} \mathrm{C}\right)$ \\
\hline \multirow[t]{3}{*}{ Hbl-granulite } & JN95B/S 1 & Opx-Cpx & Core & & 950 \\
\hline & $2 / \mathrm{J} 50 / \mathrm{S}_{1}$ & Grt-Cpx & Core & & 800 \\
\hline & & & Rim & & 660 \\
\hline \multirow[t]{8}{*}{ Two-px-granulite } & $2 / \mathrm{J} 55 / \mathrm{S}_{1}$ & Opx-Cpx & Core & & 900 \\
\hline & $1 / \mathrm{J} 12 / \mathrm{S}_{1}$ & Opx-Cpx & Core & & 800 \\
\hline & $2 / \mathrm{J} 70 \mathrm{~B} / \mathrm{S}_{1}$ & Grt-Cpx & Core & & 800 \\
\hline & & & Rim & & 750 \\
\hline & & & Core (c) & & 800 \\
\hline & & & $\operatorname{Rim}(\mathrm{c})$ & & 600 \\
\hline & $2 / \mathrm{J} 67 \mathrm{C} / \mathrm{S}_{1}$ & Grt-Cpx & Core & & 800 \\
\hline & & & $\operatorname{Rim}$ & & 650 \\
\hline Rock type & Sample no./fabric & Barometer & Location & $P$ (kbar) & $T\left({ }^{\circ} \mathrm{C}\right)$ \\
\hline \multirow[t]{2}{*}{ Khondalite } & $2 / J 96 A / S_{1}(-)$ & GRAIL & Core & $8.5(\mathrm{Fe})$ & \\
\hline & $2 / \mathrm{J} 96 \mathrm{~B} / \mathrm{S}_{2}(*)$ & GRAIL & Core & $6.2(\mathrm{Fe})$ & \\
\hline \multirow[t]{3}{*}{ Hbl-granulite } & JN95B/S 1 (\#) & GCPQ & Core & $8.6(\mathrm{Mg})$ & 740 (Grt-Cpx) \\
\hline & & & Rim & $8.6(\mathrm{Mg})$ & 640 (Grt-Cpx) \\
\hline & JN95B/S 1 (\$) & GOPCQ & Core & $9.0(\mathrm{Mg})$ & 770 (Grt-Cpx) \\
\hline \multirow[t]{3}{*}{ Two-px-granulite } & $2 / \mathrm{J}_{5} 5 / \mathrm{S}_{1}(+)$ & GOPQ & Core & $9.5(\mathrm{Mg})$ & 750 (Grt-Opx) \\
\hline & $2 / \mathrm{J}_{5} 5 / \mathrm{S}_{1}(\#)$ & GCPQ & Core & $8.9(\mathrm{Mg})$ & 825 (Grt-Cpx) \\
\hline & $2 / \mathrm{J} 154 / \mathrm{S}_{2}(\wedge)$ & GCPQ & Core & $6.3(\mathrm{Mg})$ & 600 (Grt-Cpx) \\
\hline
\end{tabular}

(-) - reaction $1(\#)-$ reaction $2,(\$)$ - reaction $3,(+)$ - reaction $4,(*)-\operatorname{reaction} 5,\left(^{\wedge}\right)-$ reaction 6 ,

(c) - coronal garnet on $\mathrm{Cpx}$, core and rim are points away from and adjacent to

Opx - Orthopyroxene, Grt - Garnet, Cpx - Clinopyroxene

GCPQ - garnet-clinopyroxene-plagioclase -quartz barometer

GRAIL $\quad-$ garnet-aluminosilicate-ilmenite barometer

GOPQ - garnet-orthopyroxene-plagioclase-quartz barometer

GOPCQ - garnet-orthopyroxene-plagioclase-clinopyroxene-quartz barometer

(Fe) - Calculation based on Fe-end memebers

( $\mathrm{Mg}$ - Calculation based on Mg-end memebers

Hbl-granulite - Hornblende bearing mafic granulite

Two-px-granulite - Two-pyroxene granulite

$6.2 \pm 0.5$ kbar. GCPQ barometry, applied to the reaction texture showing clinopyroxene and plagioclase inclusions in the garnet porphyroblasts (reaction 6) registered a pressure estimate of $6.3 \pm 0.5 \mathrm{kbar}$ at $600^{\circ} \mathrm{C}$.

Thus, a significant difference of pressure of equilibration, namely $\sim 8.5-9 \mathrm{kbar}$ and $\sim 6 \mathrm{kbar}$ is noted between $\mathrm{S}_{1}$ and $\mathrm{S}_{2}$. Also, high-pressure samples generally register higher temperature of the order of $900^{\circ} \mathrm{C}$ or more. Notably, this $P$ difference of ca. $2.5 \mathrm{kbar}$ is not related to the $d P / d T$ of the barometer and the $\Delta T$ (ca. $800^{\circ} \mathrm{C}$ vs. $600^{\circ} \mathrm{C}$ ) involved.

\section{$6.2 P-T-t$ path}

Although strong $\mathrm{S}_{1}$ fabric is recorded from the khondalites and pyroxene bearing granulites, a more complete record of changing pressuretemperature conditions during $\mathrm{F}_{1}$ deformation is preserved in the pyroxene bearing granulites only. The khondalites only record near peak $P$ estimates of $8.5 \mathrm{kbar}$. Pyroxene bearing granulites record cooling of about $350^{\circ} \mathrm{C}$ from peak temperatures of more than $950^{\circ} \mathrm{C}$. This cooling vector is nearly isobaric at pressures between $9.5 \mathrm{kbar}$ and $8.5 \mathrm{kbar}$ and possibly triggered the reactions (1), (2), (3) and (4) (figure 8). Subtle magnesian depletion of the garnet in relatively thicker coronas within hornblende-granulite, two-pyroxene granulite and khondalite is also consistent with this cooling (sample nos. 2/J96A and 2/J55 in table 1).

On the other hand, the $\mathrm{S}_{2}$-garnet of the khondalites, documenting reaction 5 , yield a pressure estimate of $6.2 \mathrm{kbar}$, using GRAIL barometer (table 6 ). In the two-pyroxene granulite, a pressure 


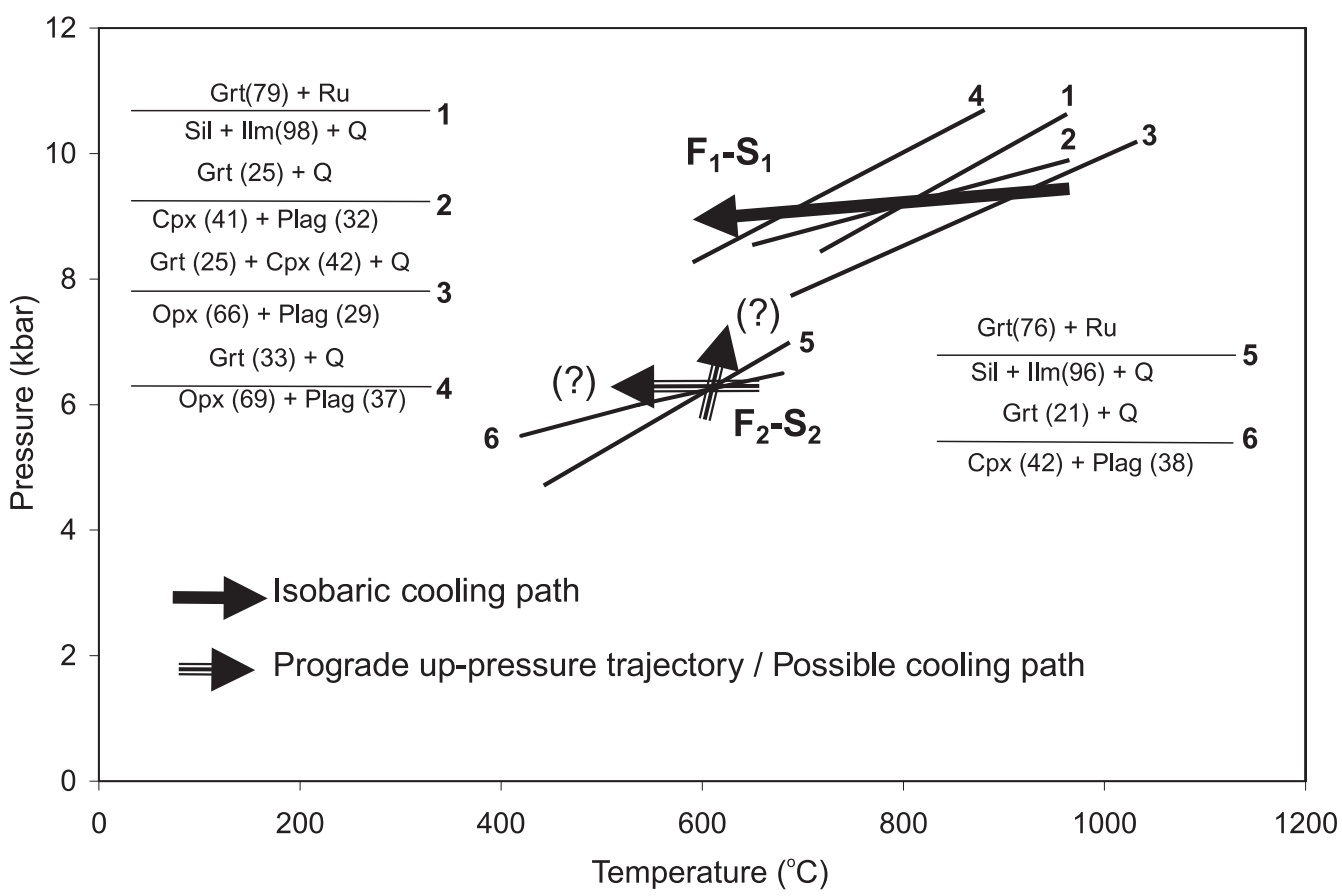

Figure 8. Pressure-temperature diagram showing the univariant lines for the studied metamorphic reactions with actual mineral compositions. Also shown are the possible $P-T$ paths, associated with two deformation episodes.

estimate of $6.3 \mathrm{kbar}$ at $600^{\circ} \mathrm{C}$, from GCPQ barometer for the reaction (6) is noted. The sense of these reactions suggests cooling at $\sim 6 \mathrm{kbar}$ pressure or a prograde pressure-increase. Formation of magnesium rich garnet overgrowths on early garnet in khondalite and marginal magnesium enrichment in relatively thicker garnet coronas on pyroxene in two-pyroxene granulite collectively point to this possible up-pressure trajectory (figure 8). An alternative interpretation, that of cooling, may still be valid. Nevertheless, there is a distinct pressure difference between the $\mathrm{S}_{1}$ and $\mathrm{S}_{2}$ metamorphic conditions. This provides strong evidence for a break in the $P-T$ evolution in this granulite complex.

\section{Discussion}

A regional granulite terrain, having the imprints of both Grenvillian and pre-Grenvillian thermal events is likely to have newly accreted crustal materials along with older reworked crustal components (Harley 1992). Another important finding regarding these terrains is that both these crustal components are typified by similar mineral assemblages, attesting to similar physical conditions over very large regions. These pose a serious problem regarding the derivation of $P$ $T$ loops; the different segments of the loop may link isotopically distinct $P-T$ vectors (Barton et al 1994).
The Eastern Ghats granulite belt, India is no exception; the belt contains all these general characteristics. Petrological evidence of polymetamorphism in the Eastern Ghats belt were presented by Grew and Manton (1986) and Sen et al (1995) from different parts of this regional granulite terrain; however, this could not be established with isotopic data. Some recent studies have pointed out the existence of several distinct crustal domains with unconnected pre-metamorphic histories (Rickers et al 2001; Bhattacharya and Gupta 2001). It is desirable, therefore, that polymetamorphism and/or reworking should be documented from the individual granulite suites in the different crustal domains in the Eastern Ghats. Note that the present area of interest is included in the domain IV (2.5-2.9 Ga) of Rickers et al (2001).

The arguments for polymetamorphism in the present study can be summarised as follows. Firstly, the geometry of the regional $F_{1}$ and $F_{2}$ folds suggests a break in the deformation history (Kar 1999, 2001), with the late deformational fabric $\left(\mathrm{S}_{2}\right)$ completely obliterating the early fabric $\left(\mathrm{S}_{1}\right)$ on local scale. Secondly, generally the mineral assemblages of $\mathrm{S}_{1}$-domains reflect a relatively high peak $P-T$ regime of $9.5 \mathrm{kbar}$ at $950^{\circ} \mathrm{C}$, whereas the $P-T$ regime of the assemblages of $\mathrm{S}_{2}$-domains is generally lower, $6.3 \mathrm{kbar}$ at $600^{\circ} \mathrm{C}$. Thirdly, the reaction textures in the assemblages of $\mathrm{S}_{1}$ fabrics indicate post-peak cooling through $200-350^{\circ} \mathrm{C}$ at $9.5-8.5 \mathrm{kbar}$, while the reaction textures in the assemblages of the $\mathrm{S}_{2}$ fabrics results 
either from cooling or an increase in pressure at $600^{\circ} \mathrm{C}$ from $6 \mathrm{kbar}$ (figure 8). The two distinct $P$ $T-D$ regimes are considered to reflect the overprinting of an Archaean high-grade metamorphism $\left(\mathrm{F}_{1}-\mathrm{S}_{1}\right)$, as documented by Bhattacharya et al (2001), by an unrelated $\mathrm{F}_{2}-\mathrm{S}_{2}$ event, most likely of Grenvillian age. The possibility of reworking of the Archaean crust during Grenvillian orogeny is interpreted from the $\mathrm{Pb}$ isotopic signatures of the Domain IV (Gupta 2004).

\section{Concluding remarks and implications}

- In regional granulite terrains with evidence of different crustal domains interpretation of geochronological data from different parts in terms of polymetamorphism is at best speculation.

- Even in the absence of isotopic data, polymetamorphism in a granulite complex may be indicated petrologically in terms of break in the $P-T$ record.

- Polymetamorphism and reworking, when established from several sectors of the regional Eastern Ghats granulite belt, will lead to better understanding of the East Gondwana correlation, especially with the Antarctic granulite belt.

\section{Acknowledgements}

Fruitful and encouraging discussion with Dr S Bhattacharya; my ideas are irretrievably entangled with his, but any misconceptions is, of course, mine! This work is a part of my unpublished Ph.D. thesis of University of Calcutta and Doctoral fellowship of Indian Statistical Institute. Infrastructure of the Geological Studies Unit, Indian Statistical Institute, Kolkata, helped greatly to complete the work. Mr A K Das has drafted the diagrams. Finally, critical but constructive comments on an earlier version of the manuscript by Prof. Simon Harley and two anonymous reviewers are thankfully acknowledged.

\section{References}

Barton J M, Holzer L, Kamber B, Doig R, Kramers J D and Nyfeler D 1994 Discrete metamorphic events in the Limpopo belt, southern Africa: Implications for the application of $P-T$ paths in complex metamorphic terrains; Geology 22 1035-1038.

Berman R G 1988 Internally consistent thermodynamic data for minerals in the system $\mathrm{Na}_{2} \mathrm{O}-\mathrm{K}_{2} \mathrm{O}-\mathrm{CaO}-\mathrm{MgO}-$ FeO- $\mathrm{Fe}_{2} \mathrm{O}_{3}-\mathrm{Al}_{2} \mathrm{O}_{3}-\mathrm{SiO}_{2}-\mathrm{TiO}_{2}-\mathrm{H}_{2} \mathrm{O}-\mathrm{CO}_{2} ;$ J. Petrol. 29 $445-522$.

Berman R G 1990 Mixing properties of $\mathrm{Ca}-\mathrm{Mg}-\mathrm{Fe}-\mathrm{Mn}$ garnets; Amer. Mineral. 75 328-344.
Berman R G 1991 Thermobarometry using multiequilibrium calculations: a new technique with petrologic applications; Canad. Mineral. 29 833-855.

Bhattacharya A and Gupta S 2001 A reappraisal of polymetamorphism in the Eastern Ghats belt - A view from north of the Godavari rift; Proc. Indian Acad. Sci. (Earth Planet. Sci.) $110369-383$.

Bhattacharya A, Krishna Kumar K R, Raith M and Sen S K 1991 An improved set of a-X parameters for $\mathrm{Fe}-\mathrm{Mg}-$ $\mathrm{Ca}$ garnets and refinements of the orthopyroxene garnet thermometer and the orthopyroxene-garnet-plagioclasequartz barometer; J. Petrol. 32 629-656.

Bhattacharya S 1996 Eastern Ghats granulite terrain of India: an overview; J. Southeast Asian Earth Sci. 14 $165-174$.

Bhattacharya S 1997 Evolution of Eastern Ghats granulite belt of India in a compressional tectonic regime and juxtaposition against Iron Ore Craton of Singhbhum by oblique collision-transpression; Proc. Indian Acad. Sci. (Earth Planet. Sci.) 106 65-75.

Bhattacharya S, Sen S K and Acharyya A 1994 The structural setting of the Chilka Lake granulite-migmatiteanorthosite suite with emphasis on the time relation of charnockites; Precamb. Res. 66 393-409.

Bhattacharya S and Kar R 2002 High-temperature dehydration melting and decompressive $P-T$ path in a granulite complex from the Eastern Ghats, India; Contrib. Mineral. Petrol. 143 175-191.

Bhattacharya S, Kar R, Misra S and Teixeira W 2001 Early Archaean continental crust in the Eastern Ghats granulite belt, India: Isotopic evidence from a charnockite suite; Geological Magazine 138 609-618.

Chetty T R K 2001 The Eastern Ghats Mobile Belt, India: A collage of Juxtaposed Terranes (?); Gondwana Res. 4 319-328.

Dasgupta S and Sengupta P 1998 Reworking of an isobarically cooled continental crust. Evidence of decompressive $P-T$ trajectory from the Eastern Ghats belt, India; Indian J. Geol. 70 133-144.

Dasgupta S, Sanyal S, Sengupta P and Fukuoka M 1994 Petrology of granulites from Anakapalle - Evidence for Proterozoic decompression in the Eastern Ghats, India; J. Petrol. 35 433-459.

Dasgupta S, Sengupta P, Fukuoka M and Bhattacharya P K 1991 Mafic granulites from Eastern Ghats, India: Further evidence for extremely high temperature crustal metamorphism; J. Geol. 99 124-133.

Dasgupta S, Sengupta P, Fukuoka M and Chakraborti S 1992 Dehydration melting, fluid buffering and decompressional $P-T$ path in a granulite complex from the Eastern Ghats, India; J. Metamorph. Geol. 10 $777-788$.

Dasgupta S, Sengupta P, Mondal A and Fukuoka M 1993 Mineral chemistry and reaction textures in metabasites from the Eastern Ghats belt, India and their implications; Mineralogical Magazine 57 113-120.

Frost B R and Chacko T 1989 The granulite uncertainty Principle: limitations on the thermobarometry in granulites; J. Geol. 97 435-450.

Fuhrman M L and Lindsley D H 1988 Ternary-feldspar modelling and thermometry; American Mineralogists $\mathbf{7 3}$ $201-216$.

Grew E S and Manton W J 1986 A new correlation of sapphirine granulites in the Indo-Antarctic metamorphic terrain: Late Proterozoic dates from the Eastern Ghats province of India; Precamb. Res. 33 123-37.

Gupta S 2004 The Eastern Ghats Belt, India - A new look at an old Orogen; Geol. Surv. India Spec. Publ. 84 75-100. 
Halden N M, Bowes D R and Dash B 1982 Structural evolution of migmatites in a granulite facies terrane: Precambrian crystalline complex of Angul, Orissa, India; Trans. Roy. Soc. Edinburgh, Earth Sci. 73 109-118.

Harley S L 1989 The origin of granulites: a metamorphic perspective; Geological Magazine 126 215-247.

Harley S L 1992 Proterozoic Granulite Terranes; In: Proterozoic Crustal Evolution. Development in Precambrian Geology 10 (ed.) Condie K C, Elsevier 301-359.

Kar R 1995 Structural setting and post-granulite modification in an area in the northeastern sector of Eastern Ghats; Indian J. Geol. 67 273-281.

Kar R 1999 Structural setting and $P-T-t$ path of the Eastern Ghats granulites adjacent to Singhbhum craton in an area around Jenapore, Orissa with special reference to the origin of charnockites: Unpublished Ph.D thesis. Calcutta University.

Kar R 2001 Evidence of Structural reworking in the Eastern Ghats Granulite belt, India: Implication for a Contiguous Supercontinent in the Proterozoic; Gondwana Res. 4 650 .

Kar R, Bhattacharya S and Sheraton J W 2003 Hornblende dehydration melting in mafic rocks and the link between massif-type charnockite and associated granulites, Eastern Ghats granulite belt, India; Contrib. Mineral. Petrol. $145707-729$.

Lal R K, Ackermand D and Upadhyay H $1987 P-T-x$ relationship from corona textures in sappihirine-spinelquartz assemblages from Paderu, south India; J. Petrol. 28 1139-1168.

Merh S S 1962 Structural aspects of the charnockitic rocks of Pallavaram, Madras state; Journal of the $M S$ University Baroda 11 123-138.

Mezger K and Cosca M A 1999 The thermal history of the Eastern Ghats Belt (India) as revealed by $\mathrm{U}-\mathrm{Pb}$ and $40 \mathrm{Ar} / 39 \mathrm{Ar}$ dating of metamorphic and magmatic minerals: implications for the SWEAT correlation; Precamb. Res. 94 251-271.

Mohan A, Tripathi P and Motoyoshi Y 1997 Reaction history of sapphirine granulites and a decompressional $P-T$ path in a granulite complex from the Eastern Ghats; Proc. Indian Acad. Sci. (Earth Planet. Sci.) 106 115-129.

Mukhopadhyay A K and Bhattacharya A 1997 Tectonothermal evolution of the gneiss complex at Salur in the Eastern Ghats granulite belt of India; Metamor. Geol. 15 719-734.

Naqvi S M and Rogers J J W 1987 Precambrian Geology of India; (Oxford: Oxford University Press) 223 pp.

Passchier C W and Trouw R A J 1996 Microtectonics; (Berlin: Springer-Verlag) $289 \mathrm{pp}$.

Rickers K, Raith M M and Dasgupta S 1998 Multistage reaction history of high $\mathrm{Mg}-\mathrm{Al}$ granulites at AnakaPalle: implications for the thermo-tectonic evolution of the Eastern Ghats belt, India; European J. Mineral. 10 233.
Rickers K, Mezger K and Raith M M 2001 Evolution of the Continental Crust in the Proterozoic Eastern Ghats Belt, India and new constraints for Rodinia reconstruction: implications from $\mathrm{Sm}-\mathrm{Nd}, \mathrm{Rb}-\mathrm{Sr}$ and $\mathrm{Pb}-\mathrm{Pb}$ isotopes; Precamb. Res. 112 183-210.

Sarkar A, Bhanumati L and Balasubramanyan M N 1981 Petrology, geochemistry and geochronology of the Chilka Lake igneous complex, Orissa state, India; Lithos 14 93-110.

Sen S K 1987 Origin of leptynites, an orthopyroxenefree granite gneiss in two granulite terranes of India, Recent Researches in Geology; In: Geological evolution of Peninsular India, Petrological and Structural aspect (ed.) Saha A K , Hindusthan Publication 13 117-124.

Sen S K and Bhattacharya S 1997 Dehydration melting of micas in the Chilka Lake Khondalites: The link between the metapelites and granitoids; Proc. Indian Acad. Sci. (Earth Planet. Sci.) 106 277-297.

Sen S K and Bhattacharya S 2000 Diverse signatures of deformation, pressure-temperature and anatexis in the Rayagada sector of the Eastern Ghats granulite terrane; Proc. Indian Acad. Sci. (Earth Planet. Sci.) 109 347-369.

Sen S K, Bhattacharya S and Acharyya A 1995 A multistage pressure-temperature record in the Chilka Lake granulites: the epitome of the metamorphic evolution of Eastern Ghats, India?; J. Metamorph. Geol. 13 287-298.

Sengupta P, Dasgupta S, Bhattacharya P K, Fukuoka M, Chakraborti S and Bhowmick S 1990 Petro-tectonic imprints in the sapphirine granulites from Anantagiri, Eastern Ghats mobile belt, India; J. Petrol. 31 971-996.

Shaw R K and Arima M 1996a High-temperature metamorphic imprint on calc-silicate granulites of Rayagada, Eastern Ghats, India: implication for the isobaric cooling path; Contrib. Mineral. Petrol. 126 169-180.

Shaw R K and Arima M 1996b Mineral chemistry, reaction textures, thermobarometry and $P-T$ path from orthopyroxene granulites of Rayagada, Eastern Ghats, India; J. Southeast Asian Earth Sci. 14 175-184.

Shaw R K and Arima M 1997 Retrograde pressuretemperature path for spinel-bearing metapelites in Rayagada, Eastern Ghats, India; Mineral. Petrol. 60 41-59.

Shaw R K and Arima M 1998 A corundum-quartz assemblage from the Eastern Ghats Granulite Belt, India: evidence of high P-T metamorphism?; J. Metamorph. Geol. 16 189-196.

Shaw R K 1996 Structural features of granulites from Rayagada, Eastern Ghats, India: some preliminary observations; J. Mineral. Petrol. Economic Geol. 91 443-454.

Vernon R H 1996 Problems with inferring $P-T-t$ paths in low- $P$ granulite facies rocks; J. Metamorph. Geol. 14 $143-153$.

Wood B J and Banno S 1973 Garnet-orthopyroxene and orthopyroxene-clinopyroxene relationships in simple and complex systems; Contrib. Mineral. Petrol. 42 109-124. 